\title{
Idiopathic Scoliosis
}

\author{
İdiyopatik Skolyoz
}

\author{
Onur YAMAN ${ }^{1}$, Sedat DALBAYRAK ${ }^{2}$ \\ ${ }^{1}$ Tepecik Education and Training Hospital , Clinic of Neurosurgery, Izmir, Turkey \\ ${ }^{2}$ Neurospinal Academy, Istanbul, Turkey
}

Corresponding Author: OnurYAMAN / E-mail: dronuryaman@yahoo.com

\begin{abstract}
Scoliosis refers to curves exceeding 10 degrees observed through posterioanterior direct radiography. In fact, the diagnosis for idiopathic scoliosis is accepted to exclude already available causes. The aim of this paper was to review the etiopathogenesis, classification systems and the treatment management of idiopathic scoliosis. A search in the National Library of Medicine (Pubmed) database using the key words 'idiopathic' and 'scoliosis' was performed. For the literature review, papers concerning the etiopathogenesis, classification and treatment were selected among these articles. A search in the National Library of Medicine (Pubmed) database using the key words 'idiopathic' and 'scoliosis' yielded 4518 articles published between 1947 and 2013. The main hypothesis put forward included genetic factors, hormonal factors, bone and connective tissue anomalies. King, Lenke, Coonrad and Peking Union Medical College (PUMC) classifications were the main classification systems for idiopathic scoliosis. Exercise, bracing and anterior, posterior or combined surgery when indicated are the choices for the treatment. Every idiopathic scoliosis case has to be managed to its own characteristics. It is the post-operative appearance that the surgeons are perhaps the least interested but the adolescent patients the most interested in. The aim of scoliosis surgery is to restore the spine without neurological deficit.
\end{abstract}

KEYWORDS: Idiopathic, Scoliosis, Review

öz

Arka-ön direkt grafide 10 derecenin üstündeki eğrilikler skolyoz olarak tanımlanır. Idiyopatik skolyoz tanısı ancak skolyoza neden olan sebepler dışlandıktan sonra koyulabilir. Bu çalışmanın amacı, idiyopatik skolyoza neden olan faktörleri, sınıflandırma sistemlerini ve idiyopatik skolyozlu hastaların tedavi yönetimini incelemektir. Elektronik arama motoru Pubmed'de 'idiopathic' and 'scoliosis' kelimeleri ile arama yapıldı. Değerlendirme için etyopatgonez, sınıflama ve tedavi ile ilgili olanlar makaleler derleme makalesine dahil edildi. Elektronik arama motoru Pubmed'de 'idiopathic' and 'scoliosis' kelimeleri ile arama yapıldığında 1947 ve 2013 yılları arasında toplam 4518 makale bulundu. İdiopatik skolyoz gelişimine neden olan faktörler içinde genetik, hormonal, kemik ve bağ dokusuna ait patolojiler ön plana çıkmaktadır. King, Lenke, Coonrad ve Peking Union Medical College (PUMC) sınıflandırma sistemleri idiyopatik skolyozu değerlendirmede kullanılan temel sınıflandırma sistemleridir. Egzersiz, korse kullanımı ve hastaya göre anterior girişim, posterior girişim ya da kombine girişimle yapılan cerrahiler tedavi seçenekleri içindedir. İdiyopatik skolyozlu her hasta kendine ait özellikleri içinde değerlendirilmelidir. Cerrahların en az ilgilendikleri ancak özellikle gelişme çağındaki idiyopatik skolyozlu hastaların en çok ilgilendikleri cerrahi sonrası nasıl görünecekleridir. İdiyopatik skolyoz cerrahisindeki temel amaç hastalarda nörolojik komplikasyon yaratmadan eğriliği fizyolojik sınırlara getirmektir.

ANAHTAR SÖZCÜKLER: İdiyopatik, Skolyoz, Derleme

\section{INTRODUCTION}

Scoliosis refers to curves exceeding 10 degrees observed through posterioanterior direct radiography (16). Scoliosis forms a complex curve that leads to deformities not only in the coronal plane but also in all three planes, which is caused by the self-rotating movement of the spine. Idiopathic scoliosis corresponds to around $80 \%$ of structural coronal deformities (35). In fact, the diagnosis for idiopathic scoliosis is accepted to exclude already available causes. It is divided into three sub-groups according to the age as infantile (age 0-3), juvenile (age 4-9) and adolescent (age 10 up to maturity).

While the incidence rate for curves of 10 degrees and above varies between 1 and $3 \%$, the incidence rate decreases to 0.15 to $0.3 \%$ when it comes to curves of 30 degrees and above, which require treatment. The female/male ratio is $1.4 / 1$ in curves of 10 degrees and above, whereas it increases to 5/1 for curves of more than 30 degrees (34).

A search in the National Library of Medicine (Pubmed) database using key words 'idiopathic' and 'scoliosis' yielded 4518 papers published between 1947 and 2013. For the literature review, papers concerning the etiopathogenesis, classification and treatment were selected. A total of 348 papers that did not comply with the literature review criteria were excluded.

\section{ETIOPATHOGENESIS}

A search using the key words 'idiopathic', 'scoliosis' and 'etiology' yielded 1211 articles, and this indicates that causes of scoliosis have not yet been definitely established and the search for causes are still continuing. The main hypothesis put forward includes genetic factors, hormonal factors, bone 
and connective tissue anomalies and autonomous nervous system dysfunctions. All the above mentioned causes are interconnected with mutual effects on each other.

\section{Genetic-Hormonal Causes}

A search using the key words 'idiopathic', 'scoliosis' and 'gene' yielded 166 papers. Articles regarding the genetic causes (COL1A1, COL1A2, COL2A1, FBN1, elastine) of Marfan or EhlerDanlos triggered by disorders of the extracellular matrix, neuromuscular disorders (Friedrich Ataxia, muscular dystrophies, osteochondrodystrophies (osteogenesis imperfecta, neurofibromatosis), and disorders that co-exist with segmentation anomalies of the vertebrae were excluded from the literature review, leaving 86 articles to be included.

Idiopathic scoliosis observed in identical twins indicates that the causes may be of genetic origin (34). Studies aimed at determining how the disorder is handed down to generations have reported that idiopathic scoliosis is not inherited in an autosomal dominant or X-linked dominant manner except for a couple of familial forms $(10,20,28,30$, $83,85,105)$. It was discovered that idiopathic scoliosis has multi-factorial hereditary characteristic and multiple genes are affected for the development of the disease. Genes found to be linked with idiopathic scoliosis include SNTG1 (gamma-1-syntrophin) in 8q11.22, ESR1 (estrogen receptor-1) in 6q25.1, CHD7 (chromodin helicase DNA binding protein $7)$ in $8 q 12.1(7,104)$. Matrilin-1 is a non-collagenous protein secreted by chondrocytes. Matrilin-1 (MATN1) protein ensures the distribution of chondrocytes within the growth plane. Montanaro discovered that MATN1 single nucleotide polymorphism in 1 p35 led to a disorder of chondrocyte distribution and caused scoliosis (61), whereas single nucleotide polymorphism at the Matrilin receptor level caused idiopathic scoliosis MTNR1B in 11q21-q22. Furthermore, an association between IS and Calmodulin1 (CALM1) gene polymorphisms has been reported (106). Esposito et al. showed that steroid binding protein polymorphisms were effective in IS development (26). IS related zones were spotted in 6q, 10q and18q, 17p11.2, 19p13.3, 8q11, Xq2326.1, 9q31.3-q34.3, 5q13-q14 and 3q11-q13, 9q31.2-q34.2, 17q25.3-qtel chromosomes $(4,7,14,38,58,68,87,103)$.

ACTB and GAPDH $\beta$-actin protein account for the protective molecules of the cell that are responsible for glyceraldehyde3-phosphate-dehydrogenase, and glycolysis secretion (90). Lack of protective molecules was found in familial idiopathic scoliosis (97).

Lebouf et al. indicated that estrogen had some impact not on the development of idiopathic scoliosis but on the degree of the curve. Later on it was discovered that such impact was more due to the insufficiency at the receptor level rather than decreasing levels of hormone secretion (53). Core receptors in bone cells, namely estrogen receptor alpha and beta, were shown to have an impact on AIS curves $(29,77)$.

The melatonin hormone causes an increase in osteoblasts and a decrease in osteoclasts. Thillard reported scoliosis development after removal of the pineal glands (95). Decreasing melatonin levels were held responsible $(6,23$, 51). Melatonin receptor-2 (MT-2) levels were observed to be lower in AIS patients with accompanying lower melatonin responses. The co-effect of 17-beta-estradiol and melatonin on osteoblastic cells obtained from AIS patients was shown to be higher than their individual effects (47). Wang et al. indicated that tryptophan hydroxylase 1 (TPH1) was one of the enzymes playing a role in melatonin synthesis. Polymorphism in the TPH-1 gene results in decreased levels of melatonin, which in turn causes idiopathic scoliosis development (98).

Calmodulin is the secondary indicator for melatonin and has an impact on muscle contraction. Relatively higher levels of calmodulin were detected in the muscles on the convex side compared to the concave side in adolescent idiopathic scoliosis (1).

Park et al. discovered that the osteogenic differentiation capabilities of mesenchymal stem cells decreased in idiopathic scoliosis patients (71). It is known that osteopenia develops in the spinal bone structure during idiopathic scoliosis. One reason for the osteopenia is the Bsm I polymorphism in the Vitamin D receptor (VDR) gene (93). (Table I provides an overview of articles concerning hormonal and genetic causes of idiopathic scoliosis and related remarks).

\section{Biomechanical Causes}

Adams discovered that an existing deformity increased by bending forward (2). The spine has a fixed rotational direction. Posterior elements make an attempt to rotate towards the concave side, and they try to make the shortest advancement just like an athlete running at the extreme interior lane of a marathon course. Therefore, the perpendicular distance is shorter on the posterior side of the vertebrae compared to the relevant distance on the anterior side (91).

In a normal spine, the rotational axis crosses the thoracic region from the anterior. This prevents bending of the thoracic region when compressed. However, lordosis development in this area forces the vertebrae to transcend the rotational axis, whereby the area is made susceptible to bending. This is the reason why patients have an increased deformity by bending forward. A vertebra shall move in two ways under compression. Either kyphosis or lordo-scoliosis will develop. Furthermore, biomechanical studies have shown that in order to ease the load, the loaded vertebra shall; 1) increase the existing curve 2 ) extend its length and 3 ) increase its inner load (59).

Anatomical studies have shown that the corpus vertebrae develop a deformity at the axial sections of T4-T9 due to the descending thoracic aorta, as a result of which the thoracic curves bend towards the right side (27).

\section{CLASSIFICATION Of IDIOPATHIC SCOLIOSIS}

A search on the classification of idiopathic scoliosis yielded 310 papers. Since the SRS, Schwab and Aebi classifications are about classifications for adult scoliosis, they were excluded 
Table I: An Overview of Papers Concerning Hormonal and Genetic Causes of Idiopathic Scoliosis and Related Remarks

\begin{tabular}{|c|c|}
\hline Reference Paper & Conclusion-Findings \\
\hline Wise et al. (2000) (103) & The idiopathic scoliosis gene loci are present on chromosomes $6,10,18$. \\
\hline Salehi et al. (2002) (87) & The idiopathic scoliosis associated gene locus is present on chromosome $17 p 11$. \\
\hline Chan et al. (2002) (14) & $\begin{array}{l}\text { The familial idiopathic scoliosis associated gene locus is present on chromosome } 2 \text { and } \\
\text { 19p13.3. }\end{array}$ \\
\hline Miller et al. (2012) (58) & $\begin{array}{l}\text { The familial idiopathic scoliosis associated gene locus is present on chromosomes } \\
9 q 31.3-q 34.3 \text { and } 16 p 12.3-q 22.2 \text {. }\end{array}$ \\
\hline Ocaka et al. (2008) (68) & $\begin{array}{l}\text { The familial adolescent idiopathic scoliosis gene locus is present on chromosomes } \\
9 q 31.2-q 34.2,17 q 25.3-q \text { tel. }\end{array}$ \\
\hline Edery et al. (2011) (24) & The IS associated gene locus is present on $5 q 13-q 14$ and $3 q 11-q 13$ \\
\hline Alden et al. (2006) (4) & The idiopathic scoliosis associated gene locus is present on chromosome 19. \\
\hline Chan et al. (2009) (-) & rs 1149048 polymorphism in MATN1 causes a progression of the curve in AIS. \\
\hline Jiang et al. (2012) (37) & $\begin{array}{l}\text { Matrix metalloproteinases (MMPs) and activator inhibitors (TIMP-2) play a role in } \\
\text { endochondral ossification. } \\
\text { SNP (rs8179090) in gene TIMP-2 causes an increase in the thoracic curve of AIS. }\end{array}$ \\
\hline Kou et al. (2013) (42) & $\begin{array}{l}\text { GPR126 (encoding G protein-coupled receptor } 126 \text { ) is secreted from the cartilage. } \\
\text { Suppression of GPR126 causes delays in spine development. SNP in } 6 q 24.1\end{array}$ \\
\hline Lee et al. (2010) (44) & $\begin{array}{l}\text { IL6-572 G-->C polymorphism decreases bone density in the lumbar region and it is } \\
\text { associated with the AIS. }\end{array}$ \\
\hline Morocz et al. (2011) (63) & $\begin{array}{l}\text { SNPs in bone morphogenetic protein } 4 \text { (BMP4), interleukin-6 (IL6), leptin, matrix } \\
\text { metalloproteinase-3 (MMP3) and melatonin 1B receptor (MTNR1B) genes causes AIS. }\end{array}$ \\
\hline Qiu et al. (2012) (78) & Polymorphism in Neutrophin-3 (NTF3) gene has an impact on the curve caused by AIS. \\
\hline Peng et al. (2012) (72) & $\begin{array}{l}\text { SNPs in GPER receptor ( } r \text { s3808351, rs10269151 and rs426655s3) genes have an impact on } \\
\text { the degree of the curve in AIS. }\end{array}$ \\
\hline Waller et al. (2013) (97) & ACTB and GAPDH protective molecules are associated with the familial idiopathic scoliosis. \\
\hline Wang et al. (2008) (98) & $\begin{array}{l}\text { Polymorphism of the triptophan hydroxylase }(\mathrm{TPH} 1) \text { with a role in melatonin synthesis is } \\
\text { associated with AIS. }\end{array}$ \\
\hline Zhao et al. (2009) (106) & $\begin{array}{l}\text { Polymorphism of Calmodulin } 1 \text { (CALM1) and estrogen receptor-a genes is associated with } \\
\text { AIS. }\end{array}$ \\
\hline Acaroglu et al. (2009) (1) & $\begin{array}{l}\text { Higher levels of calmodulin were detected in the muscles on the convex side compared to } \\
\text { the concave side, in adolescent idiopathic scoliosis. }\end{array}$ \\
\hline Zhou et al. (2012) (107) & An association has been discovered between the polymorphism of IL-17RC gene and AIS. \\
\hline Esposito et al. (2009) (26) & Polymorphism of steroid binding protein has an influence on IS development. \\
\hline Leboeuf et al. (2009) (43) & Estrogen hormone has an influence on the degree of the curve in idiopathic scoliosis. \\
\hline Letellier et al. (2008) (47) & $\begin{array}{l}\text { 17-beta-estradiol and melatonin were observed to have a higher influence on the AIS } \\
\text { osteoblast cells. }\end{array}$ \\
\hline Man et al. (2011) (55) & Lower levels of Melatonin 2 (MT2) receptors were discovered in AIS. \\
\hline Suh et al. (2010) (93) & $\begin{array}{l}\text { Bsm I polymorphism in Vitamin D receptor (VDR) gene has an influence on AIS } \\
\text { development. }\end{array}$ \\
\hline Park et al. (2009) (71) & $\begin{array}{l}\text { It was discovered that osteogenic differentiation capabilities of mesenchymal stem cells } \\
\text { degraded in idiopathic scoliosis. }\end{array}$ \\
\hline
\end{tabular}

SNP: single nucleotide polymorphism. 
Table II: King Classification: Scoliosis is Divided into 5 Sub-Groups According to the Main Curve and Compensatory Curve (41)

\begin{tabular}{c|l|l|l|}
\hline \multicolumn{5}{|l|}{ King Classification } \\
\hline Type & Primary Curve & Secondary Curve & Lateral Bending \\
\hline I & Lumbar, crossing the midline & Thoracic, crossing the midline & Lumbar curve is larger \\
II & Thoracic, crossing the midline & Lumbar, crossing the midline & Thoracic curve is larger \\
III & Thoracic & Lumbar, not crossing the midline & - \\
IV & Long Thoracic & Where L5 is centered over the sacrum & - \\
\hline \multirow{2}{*}{ V } & Double Thoracic & & - \\
\hline
\end{tabular}

Table III:Structural Criteria for the Minor Curve

$$
\text { Structural Criteria (for minor curves) }
$$

Proximal Thoracic $\quad$ Cobb $>25^{\circ}$ at lateral bending

T2-5 kyphosis $>+20^{\circ}$

Main Thoracic

$\mathrm{Cobb}>25^{\circ}$ at lateral bending

T10-L2 kyphosis $>+20^{\circ}$

Thoracolumbar/lumbar $\mathrm{Cobb}>25^{\circ}$ at lateral bending

T10-L2 kyphosis $>+20^{\circ}$

from the literature review. The papers found were mainly based on King, Lenke, Coonrad and Peking Union Medical College (PUMC) classifications.

\section{King Classification}

King-Moe was the first classification for idiopathic scoliosis (41). King et al. classified scoliosis into 5 sub-groups according to the location of the curve (Table II). The terminology adopted include structural and compensatory (secondary) curve, and the flexion index was defined as the difference between the rate of correction in the lumbar curve and the rate of correction in the thoracic curve at lateral bending direct radiography. King classification initially considered that the lumbar curve was compensatory and argued that selective fusion would be adequate. Based on this argument, 405 patients with thoracic scoliosis received selective thoracic fusion by the help of a Harrington rod system in their series. Richards et al. discovered that spinal imbalance developed in the post-surgery period of selective thoracic fusion in patients with a lumbar curve of 40 degrees and above (81). Roye et al. also found that King type II and III patients developed major spinal imbalance once segmental instrumentation was applied (86). Cummings in 1998 and later Behensky et al. in 2002 discussed the reproducibility and reliability of the King Classification in their papers and stated that the classification was poor in terms of reproducibility and reliability since it did not explain thoracolumbar, lumbar, double major and triple curves and it did not consider the sagittal alignment disorder $(9,21)$

\section{Lenke Classification (two-dimensional classification)}

While the structural curve is considered as the biggest (major) curve, the other two curves are considered minor. There are some criteria according to which one can determine whether the minor curves are structural (Table III). In addition to the 6 types of curves (I-VI), the Lenke classification also provides for definitions of lumbar spine modifier and sagittal spine modifier (Table IV) (45). Lenke Type I curve features a major curve in the main thoracic region. Curves in proximal thoracic (PT) and lumbothoracic (LT/L) regions are minor and nonstructural. Lenke Type II curve features a double thoracic curve. Curves in proximal thoracic (PT) and main thoracic (MT) regions are structural, but the curve in the lumbothoracic region is non-structural. Lenke Type III curve features a major curve in the main thoracic region and a structural curve in the thoracolumbar region. Triple curves are defined at Lenke Type IV. In Lenke Type V, major curve is in the thoracolumbar (TL) junction. Curves in the proximal thoracic (PT) and main thoracic (MT) regions are non-structural. Lenke Type VI features a structural curve in the main thoracic (MT) and thoracolumbar /lumbar regions. The curve in $\mathrm{TL} / \mathrm{L}$ is bigger than the curve in the MT.

Lenke et al. assessed the reliability of their own classification system and rated it as $93 \%$ reliable (46). Five different surgeons conducted a comparative analysis of Lenke classification and King classification, the results of which indicated that Lenke classification had a reliability of $85 \%$, with a kappa value of 0.83 , whereas King classification had a reliability of $69 \%$ with a kappa value of 0.69. Lenke classification was reported to have an interobserver reliability of $85 \%$. Lenke et al. conducted in association with several surgeons indicated a reliability level of 84 to $90 \%$ for the new classification (46). Ogon stated that Lenke classification was more reliable than the King classification, but it involved some problems concerning the assessment of upper thoracic and lumbar curves (69).

Nimeyer et al. stated that both King and Lenke classifications were reliable (67). Harms Working Group reviewed 1281 cases of Lenke et al. retrospectively, and indicated that Lenke did not comply with his own classification in 192 (15\%) cases. The 'violation of the rule' was most frequently observed for Lenke Type 3. Newton et al. reviewed 203 cases of Lenke Type IB and Type IC post-fusion (Lenke classification suggests that only the structural curve should be included in the fusion, while stating that the lumbar region should not be included in the fusion). The common feature of non-selective cases 
(where lumbar region was also included in the fusion), i.e. 'violation of the rule', was found to be the long lumbar curve before surgery and apical vertebrae very far away from the central sacral vertical line (CSVL). The rate of 'violation of the rule' was determined as 32\% for Lenke Type IC patients and $8 \%$ in Type IB (66). Having regard to the review by Newton, it is recognized that the non-structural lumbar region also

Table IV: Lumbar Spine Modifier Is Defined According to the Central Sacral Vertical Line (CSVL). Types A, B and C are Determined Depending on the Central Sacral Vertical Line Position to the Apical Vertebrae. Thoracic Spine Modifier Is Determined As Hypokyphotic, Normokyphotic or Hyperkyphotic According to the Cobb Angle at the Sagittal Plane

\begin{tabular}{|c|c|}
\hline \multicolumn{2}{|c|}{ Lumbar Spine Modifier } \\
\hline Type A & $\begin{array}{l}\text { CSVL passes between pedicles of apical lumbar } \\
\text { vertebrae. }\end{array}$ \\
\hline Type B & CSVL touches pedicle of apical lumbar vertebrae. \\
\hline Type C & CSVL does not touch apical lumbar vertebrae. \\
\hline \multicolumn{2}{|c|}{ Thoracic Spine Modifier } \\
\hline & Sagittal Cobb Angle at T5 to T12 \\
\hline Нуро (-) & $<10$ degrees \\
\hline Normo N & $10-40$ degrees \\
\hline Hyper (+) & $>40$ degrees \\
\hline
\end{tabular}

has an influence on intraoperative surgical decision-making. The Lenke classification has a weakness of not regarding the rotation of lumbar region before the surgical decision is made.

While treating the curve, surgeons tend to violate the basic rules of Lenke Classification by $15 \%$. The Lenke Classification does not clearly state the lowest and highest limit of fusion; neither does it indicate the extent to which the structural curve should be included in the fusion. The classification does not consider shoulder imbalance, patient maturity or body balance. However, compared to the King Classification, the Lenke Classification is useful for the surgeon to use a common vocabulary while describing the curve.

\section{Coonrad Classification}

Coonrad et al. reviewed 2000 cases of idiopathic scoliosis and described 21 curve types (18). The author indicated $98.7 \%$ and $100 \%$ for the interobserver and intraobserver reliability of the Coonrad Classification, respectively. Behensky et al. reported an interobserver reliability level of kappa 0.38 for Coonrad Classification. The use of this classification has not been widespread as it only considered the coronal plane (9).

\section{PUMC Classification System (Peking Union Medical College)}

Qiu et al. defined the PUMC Classification system in 2005. This method is useful to determine the surgical approach and define the related fusion levels, and there are 3 main

Table V: Papers and Remarks about the Classification Systems for Idiopathic Scoliosis

Reference $\quad$ Remarks

Richards BS (1992) (82)

Roye et al. (1992) (86)

Cummings et al. (1998) (21)

Behensky et al. (2002) (9)

Lenke et al. (1998) (46)

Lenke et al. (2001) (45)

Niemeyer et al. (2006) (67)

Ogon et al. (2002) (69)

Newton et al. (2003) (66)

Qui et al. (2008) (80)

\section{Remarks}

Spinal imbalance develops after selective thoracic fusion in King Type II patients with a lumbar curve greater than 40 degrees.

Selective thoracic fusion causes significant spinal imbalance in King Type II and Type III patients.

Reliability and reproducibility of the King Classification System is poor since it does not explain thoracolumbar, lumbar, double major and triple curves and take into account the sagittal alignment disorder.

Reliability of the Coonrad and King classification systems is poor. Both systems are inadequate in classifying upper thoracic and lumbar curves.

The reliability of the King Classification system in identifying the curve type is poor; it is therefore rarely used to guide the treatment approach.

Many surgeons can have a consensus by $84-90 \%$ on the curve type identified and its degree by using the Lenke Classification system.

King and Lenke classification systems are both reliable.

The Lenke Classification system is more reliable than the King classification system; however, it causes some issues in evaluating the upper thoracic and lumbar curves.

There is a rule violation by $32 \%$ in Lenke Type IC (The non-structural lumbar region was contained in the fusion). The Lenke classification cannot indicate the fusion levels clearly.

When the PUMC and Lenke classification systems are compared, PUMC appears to be relatively simpler and to cause less confusion in surgical planning. 
categories as Type I (single curve), Type II (double curve) and Type III (triple curve) with a total of 13 sub-types (79).

Comparing the PUMC and Lenke Classification systems, Qui et al. stated that the PUMC Classification system is relatively simpler and the inter- and intra-observer variability caused less confusion in surgical planning (80).

None of the existing classification systems is ideal to diagnose and treat scoliosis. Table $V$ shows brief information about the papers published on the reproducibility and reliability of the concerned classification systems.

\section{Natural History}

It is important to know the natural history of idiopathic scoliosis for treatment planning. There must be 5 to 10 degrees increase in the curves to define progression. The degree of the curve and the remaining growth potential of the patient should be known prior to the treatment planning. The Risser sign (39, 48,84 ) and the shape of the distal phalanx epiphysis provide information about the maturation process (88). Peak height velocity in girls should particularly be taken into account. This period corresponds to the time of 6 months before menarche in girls. This is the period when the progression in scoliosis is the fastest. The peak growth velocity terminates with the menarche and growth decelerates gradually following this period.

According to Bunnel and Lonstein, $70 \%$ of the patients with Risser sign 0 , and curves of 20-30 degrees progressed 5 degrees or more. Weinstein stated that the curve could still progress although the patients he had followed-up for 40 years completed their maturation process (102). Nachemson reported that the curve might progress by up to 6 degrees in $66 \%$ of the patients with a curve between 20 to 30 degrees (64). Large curves (30-40 degrees) progress more than the minor curves (20-29 degrees) $(12,75)$.

The curve type has an impact on progression as much as the curve degree does. Double curves progress more than single curves. The least progression is in the curves in the lumbar region (49). The curve progression rate in girls is higher than that in the boys $(12,102)$.

\section{TREATMENT}

\section{Exercise Therapy}

The search on the Pubmed electronic search engine with the key words 'adolescent idiopathic scoliosis' 'physiotherapy' or 'exercise therapy' or 'rehabilitation' resulted in a total of 169 papers in English by June 2013. Articles at level 3 or below for evidence-based medicine, where there was no follow-up by measurements, and that did not have at least one-year followup were excluded from this review. 9 papers were included in total (Table VI).

Negrini at al. divided 74 patients into two groups and reported the outcomes of the patients they followed for 12.1 years (65). Patients in the first group were treated by a scientific exercise specific to scoliosis whereas the patients in the $2^{\text {nd }}$ group were treated by physiotherapy. The clinical course of the patients was also followed with respect to the need for bracing and Cobb angles. $6.1 \%$ of the patients performing the scientific exercise specific to scoliosis needed bracing while this rate

Table VI: Papers on the Efficacy of Exercise Therapy in Idiopathic Scoliosis and Their Conclusions

Reference

Negrini et al. (2003) (65)

Mclntire et al. (2008) (57)

Weiss et al. (2006) (99)

Weiss et al. (2003) (100)

Weiss (1992) (101)

Mooney et al. (2003) (62)

Otman et al. (2005) (70)

Mamyama et al. (2002) (54)

Dobosiewicz et al. (2002) (22)

\section{Remarks}

Need for bracing decreased in patients performing scientific exercise specific to scoliosis, and the Cobb angle was preserved.

Curve progression was avoided for 8 months in patients (Cobb angle at 20-40 degrees) undergoing body rotation and traction through the MedX Rotary Torso.

A decrease in the lateral deviation and surface rotation was observed in patients treated by Scoliosis Intensive Rehabilitation (SIR).

Curve progression was found to decrease significantly in the group of patients treated by Scoliosis Intensive Rehabilitation (SIR) compared to the control group.

Cobb angles decrease due to the Schroth method compared to the pre-treatment values.

Cobb angles were observed to decrease in 16 out of 20 patients treated by MedX Rotary Torso.

Cobb angles were observed to decrease in a year in patients treated by Schroth's 3D exercise therapy.

No progression was observed in the Cobb angles when side shift exercise was practiced by patients with idiopathic scoliosis who reached full maturity.

208 AIS patients with a median age of 14.2 years were treated by asymmetrical body mobilization. Cobb angles were observed to decrease (no statistical data). 
was found to be $25 \%$ in the patients undergoing the classic physiotherapy. The mean Cobb angle of the patients in the $1^{\text {st }}$ group remained the same (-0.67 degrees), whereas the Cobb angle of the patients undergoing the classic physiotherapy worsened (+1.38 degrees).

Mclntire et al. treated 15 patients with a median age of 13.9 years, with Cobb angles ranging between 20-60 degrees, Risser sign III and below with physiotherapy by means of the MedX Rotary Torso Machine. It was reported that six patients with curves between 20 to 40 degrees did not progress during the 8-month follow-up period but progression could not be avoided by the end of 24-month follow-up (57). On the other hand, Mooney and Brigham who used the same method found a reduction in the Cobb angles in 16 out of 20 patients in the age group of 11-17 years (62).

Weiss et al. followed the lateral deviation surface rotation and kyphotic angle of a patient group by applying the 4-week Scoliosis Intensive Rehabilitation (SIR) program. It was observed that the lateral deviation and surface rotation decreased in the treatment group compared to the control group (99). In another group of patients who underwent the same program, progression was observed in the curves of the control group compared to the control group (100). It was stated that the Cobb angles of 107 patients treated by Schroth method fell from 43.06 to 38.96 degrees compared to the pre-treatment values (101). Cobb angles were reported to fall from 26.10 degrees to 18.85 degrees in a year in another series of patients treated by the same method (70).

Mamyama et al. treated 69 patients with idiopathic scoliosis, who reached full maturity, with the side shift exercise for 4.4 years and reported that Cobb angle fell from 31.5 degrees to 30.3 degrees (54). Dobosiewicz et al. treated 208 AIS patients with a median age of 14.2 years with asymmetrical body mobilization and reported that Cobb angles decreased by $33.6 \%$ in single curves, by $22.8 \%$ in double curves in the thoracic region, and by $26.1 \%$ in the lumbar region; however, this study has a lower value as no statistical data was used in the study (23).

\section{Bracing}

For the literature review, 'idiopathic scoliosis' and 'bracing' were used as the key words to search in the Pubmed search engine and 329 papers were found as a result. Papers on bracing for other scoliosis types, papers on conservative treatment, genetic issues and irrelevant papers were excluded from this section. 81 papers were analyzed.

For successful bracing, the existing curve should be preserved below 45 degrees until the patient reaches full maturity (81, 89). Richards et al. suggested bracing for patients with Risser sign from 0 to 2, and current curve at 25-40 degrees. Surgery is suggested for patients reaching their full maturity and with curves greater than 45 degrees (81). Lonstein found a reduction by $1-4$ degrees in $78 \%$ of 1020 patients with adolescence idiopathic scoliosis using Milwaukee braces while it was reported that $22 \%$ of the cases required surgery $(49,50)$.
Bassett treated 75 cases with a curve at 20-39 degrees, Risser sign from 0 to 1 and using Wilmington braces for 2.5 years and stated that the degree of curves in patients decreased by $50 \%$. Only $11 \%$ of the cases in this series required surgical intervention (8). In the Katz series where 51 cases with curves between 36 to 45 degrees and using Boston braces, bracing was successful in $61 \%$ of the patients while $31 \%$ of the cases required surgery (40). Coillard et al. treated 170 patients by using Spine-Cor braces and reported 59\% success rate (17). $23 \%$ of the cases required surgery.

Milwaukee, Wilmington, Spine-Cor and Boston braces appear to be superior to the other types of braces. Price reported that the outcomes of 98 patients using Charleston braces were excellent by $63 \%$. He reported that the major curves were corrected by $85 \%$ and the minor curves by $33 \%$ (74). In another series using the same braces, curve progression was stopped by $60 \%$ in the patients with Risser sign from 0 to 1 (96).

Braces should be used for 18-23 hours a day on average. Braces were reported to be effective for patients with curves less than 35 degrees when used part-time or at night (74). Braces should be used full-time by patients with curves equal to or greater than 35 degrees. Braces should be used until the end of full growth. Bracing should be continued for 18-24 months by the end of $6^{\text {th }}$ month following the end of growth, up to Risser sign 4 in girls, Risser type 5 in boys, and following the menarche in girls (89).

\section{SURGICAL TREATMENT}

\section{Indications for Surgical Treatment}

In general, curves greater than 45 and 50 degrees should be treated by surgery. It was found in the studies that curves greater than 50 degrees still progressed even after reaching full maturity (102). Edgar et al. applied a non-surgical approach for the treatment of the patients with thoracic curves between 50 to 75 degrees, Risser sign 4 and 5 for 40 years and reported a mean increase by 29.4 degrees in the curves during this period (25). In another study where patients were followed for 50 years, it was reported that the thoracic curves progressed from 60.5 degrees to 84.5 degrees on average. One should not wait for the curve to progress since surgical treatment of greater degrees of curves would increase complication rates and cause more intraoperative blood loss.

\section{Fusion Surgery}

\section{Posterior instrumentation}

Instrumentation was first used by Paul Harrington in the surgical treatment of scoliosis (32). Harington attempted to correct the curves by distraction from the concave side using the rods. The second generation instrumentation system was developed by Cotrel and Dobousett. They tried to achieve correction using rod rotation manoeuvres (19). Spine can be attached tightly to the rods by pedicle screws or hybrid systems thanks to today's advanced technology. 
Suk used the pedicle screws in the surgical treatment of deformities. He reduced the curves from 51 to 16 degrees on average (69\% correction) (94). Asher et al. reported to have achieved $63 \%$ correction by the hybrid system they applied with hooks and pedicle screws (5). Cheng et al. compared the hooks and transpedicular screws and reported no difference between both systems in terms of correction rates (15).

\section{Anterior instrumentation}

Anterior approach can be preferred as it can achieve correction with shorter fusion levels in the scoliotic thoracolumbar and lumbar regions. Postoperative pain and scar formation decrease in patients with the introduction of the videoassisted thoracoscopic surgery $(76,92)$. Potter compared anterior and posterior fusion for thoracic curves and reported that posterior approach achieved better correction compared to the anterior approach (73). Hee et al. reported no difference in the coronal plane between the anterior instrumentation and pedicle screws in patients with adolescence idiopathic scoliosis (33).

\section{Determining the Fusion Levels}

Right Thoracic Curves (Lenke Type 1: Main Thoracic Curve)

This is the most frequent curve type. There is a major curve in the main thoracic region. Curves in the proximal thoracic (PT) region and lumbothoracic (LT/L) region are minor and non-structural. All curves in this type can be treated by posterior instrumentation and fusion. T3, T4 or T5 that will be instrumented as the upper vertebrae while lower instrumented vertebrae (LIV) depends principally on the lumbar spine modifier (45).

Lower instrumented vertebrae (LIV) of a patient with the lumbar spine modifier $A$ should be the one that the central sacral vertical line (CSVL) intersects in the TL/L region. This is usually one level below the lower end vertebrae (LEV) of MT.

The same technique shall apply to the patients with $1 \mathrm{~B}$ curves. Lenke suggested for patients with curve modifier B that some residual tilt should be preserved in the LIV due to the lumbar apical deviation of curves (45).

It is suggested to go down to the stable vertebrae (SV) for patients with $1 \mathrm{C}$ modifier curves. This should be T11 or T12. Sagittal balance should also be taken into account in determining the lowest level of the fusion. It should ensured that the junctional kyphosis was also contained in the fusion to maintain the sagittal balance. Selective thoracic fusion for patients with $1 \mathrm{C}$ curves would be useful to preserve the lumbar range of motion of the patients (45).

\section{Double Thoracic Curve (Lenke Type 2)}

Proximal thoracic (PT) curves and main thoracic (MT) curves are the structural curves. However, lumbothoracic curves are non-structural. The upper instrumented vertebrae (UIV) should be T2 or T3. On the other hand, LIV should be selected according to the procedure applied to Lenke Type I depending on the lumbar spine modifier. One of the basic rules to take into account in PT curves is to preserve the shoulder balance. Left shoulder is usually higher than the right one (in right MT, left PT curves). In order to achieve the shoulder balance, it is necessary to apply compression forces on the convex side of the PT and distraction forces on the concave side of the PT (45).

Although rarely observed, UIV should also be T2 or T3 for Lenke Type 2 curves where right shoulder is higher. Shoulder balance should be achieved in correcting the MT curves. Left shoulder should not be lifted too high while achieving the shoulder balance in selected patients for whom the fusion level starts at T4 and T5 and PT is not contained in the fusion (45).

\section{Double Major Curve (Lenke Type 3)}

There is a major curve in the main thoracic region and a structural curve in the thoracolumbar junction. The UIV should be T3, T4 or T5 depending on the non-structural PT curve with shoulder imbalance just like in Lenke Type 1. LIV should usually be extended to L3 or L4 (45). If the apex of the $T L / L$ curve is on or lower than $L 2, L 3-4$ disc is convex or open on the convex side of the TL/L curve and $L 4$ has a rotation of 1 degree or greater according to Nash-Moe classification, the fusion should be extended to L4 (45).

If the apex of the TL/L curve is on or higher than $L 1-2, L 3-4$ disc is neutral or closed on the convex side of the TL/L curve and if $L 4$ has a rotation of 1.5 degrees and lower according to Nash-Moe classification, L3 should be selected as the LIV. Type 3 curves usually have $C$ spine modifier. Curves with $A$ and $B$ spine modifier have wide-angle MT curves, which makes the $T L / L$ curve structural in the lateral bending $x$-rays.

\section{Triple Major Curve (Lenke Type 4)}

Since the proximal thoracic (PT), main thoracic (MT) and thoracolumbar/lumbar (TL/L) curves are structural, three curves should be contained in the fusion. UIV should be selected as in Lenke Type 2 while LIV should be selected as in Lenke Type 3. Fusion level usually ranges between T2, T3 and L3, L4 (45).

\section{Thoracolumbar and Lumbar Curves (Lenke Type 5)}

Main curve is in the thoracolumbar (TL) junction. Curves in proximal thoracic (PT) and main thoracic (MT) regions are non-structural. UIV should be the vertebrae one level or two level above the USV, whereas the vertebrae one level or two level below the LSV should be selected as the LIV.

\section{Main Thoracolumbar / Lumbar Curve (Lenke Type 6)}

The curve in the proximal thoracic region is non-structural. The curve in the main thoracic region is structural. The curve in the thoracolumbar/lumbar region is larger than the one in the main thoracic region. Both curves should be contained in the fusion (Figure 8). The surgical limits should be determined according to the principles applying to the Type 3 curves. 


\section{Non-Fusion Surgery}

Non-fusion surgery is another option in order to control growth in the treatment of idiopathic scoliosis. Progression of the curve might be avoided by means of instrumented or non-instrumented epiphysiodesis on the convex side of the curve.

Betz et al. stated that preventing the growth in front of the vertebral column will also prevent the progression of adolescence idiopathic scoliosis whereas Marks argued that preventing the anterior and posterior growth in infantile scoliosis alone cannot stop the progression of the deformity $(11,56)$.

After the fusion surgery at younger ages, the body remains shorter than the limbs. Shorter body prevent the development of lungs. Some techniques for the correction of the existing curve while also allowing the growth of the spine have been developed $(31,60)$. The upper and lower parts of the curve can be fixed by Isula double rod system developed by Akbarnia, attached to the rods and the rods are attached to one another with an additional rod. The rods are extended in 6-month follow-up. After reaching the full growth, fusion is completed with instrumentation. The degree of the curves which was preoperatively 82 on average was reduced to 38 degrees and then 36 degrees following an average 6.6 extension surgery as a result of this method applied on 23 patients between 1993 and 2001 (3).

Vertical expandable prosthetic titanium ribs (VEPTR) were developed to treat the thoracic insufficiency syndrome that is caused by combination of ribs and curves (13). The deformity can be corrected acutely by means of VEPTR following the wedge thoracostomy. VEPTR device is expanded in 4-6 months time. Seventy two patients with a mean age of 3.2 years were treated with this device for 5.7 years and it was reported that the vital capacity increased and also the curve degree was reduced from 72 on average to 49 (13).

\section{CONCLUSION}

It is the post-operative appearance that the surgeons are perhaps the least interested but the adolescence patients are the most interested. It is essential to avoid breast asymmetry and achieve shoulder balance for girls. Rib humps that can be recognized by the adolescent or her peers over the clothing should be reduced to acceptable surgical limits postoperatively.

\section{REFERENCES}

1. Acaroglu E, Akel I, Alanay A, Yazici M, Marcucio R: Comparison of the melatonin and calmodulin in paravertebral muscle and platelets of patients with or without adolescent idiopathic scoliosis. Spine (Phila Pa 1976) 34(18):E659-663, 2009

2. Adams W: Lectures on the Pathology and Treatment of Lateral and other Forms of Curvarure of the Spine. London: Churchill and Sons, 1865
3. Akbarnia BA, Marks DS, Boachie-Adjei O, Thompson AG, Asher MA: Dual growing rod technique for the treatment of progressive early-onset scoliosis. Spine 30: 546-555, 2005

4. Alden KJ, Marosy B, Nzegwu N, Justice CM, Wilson AF, Miller $\mathrm{NH}$ : Idiopathic scoliosis: Identification of candidate regions on chromosome 19p13. Spine 31: 1815-1819, 2006

5. Asher MA, Lai SM, Burton D, Manna B, Cooper A: Safety and efficacy of Isola instrumentation and arthrodesis for adolescent idiopathic scoliosis: Two- to 12-year follow-up. Spine 29:2013-2023, 2004

6. Bagnall K, Raso VJ, Moreau M, Mahood J, Wang X, Zhao J: The effects of melatonin therapy on the development of scoliosis after pinealectomy in the chicken. J Bone Joint Surg 81: 191-199, 1999

7. Bashiardes S, Veile R, Allen M, Wise CA, Dobbs M, Morcuende JA, Szappanos L, Herring JA, Bowcock AM, Lovett M: SNTG1, the gene encoding gamma1-syntrophin: A candidate gene for idiopathic scoliosis. Hum Genet 115: 81- 89, 2004

8. Bassett GS, Bunnell WP, MacEwen GD: Treatment of idiopathic scoliosis with the Wilmington brace. Results in patients with a twenty to thirty-nine-degree curve. J Bone Joint Surg Am 68:602-605, 1986

9. Behensky H, Giesinger K, Ogon M, Krismer M, Hannes B, Karlmeinrad G, Michael O, Martin K: Multisurgeon assessment of coronal pattern classification systems for adolescent idiopathic scoliosis: Reliability and error analysis. Spine 27:762-767, 2002

10. Bell $M$, Teebi AS: Autosomal dominant idiopathic scoliosis? Am J Med Genet 55: 112, 1995

11. Betz RR, Kim J, D'Andrea LP, Mulcahey MJ, Balsara RK, Clements DH: An innovative technique of vertebral body stapling for the treatment of patients with adolescent idiopathic scoliosis: A feasibility, safety, and utility study. Spine 28:S255-265, 2003

12. Bunnell WP: The natural history of idiopathic scoliosis before skeletal maturity. Spine 11:773-776, 1986

13. Campbell RM, Smith MD, Mayes TC, Mangos JA, WilleyCourand DB, Kose N, Pinero RF, Alder ME, Duong HL, Surber $\mathrm{JL}$ : The effect of opening wedge thoracostomy on thoracic insufficiency syndrome associated with fused ribs and congenital scoliosis. J Bone Joint Surg Am 86:1659-1674, 2004

14. Chan V, Fong GC, Luk KD, Yip B, Lee MK, Wong MS, Lu DD, Chan TK: A genetic locus for adolescent idiopathic scoliosis linked to chromosome 19p13.3. Am J Hum Genet 71: 401- 406, 2002

15. Cheng I, Kim YJ, Gupta MC, Bridwell KH, Hurford RK, Lee SS, Theerajunyaporn T, Lenke LG: Apical sublaminar wires versus pedicle screws-which provides better results for surgical correction of adolescent idiopathic scoliosis? Spine 30: 2104-2112, 2005

16. Cobb JR: Outline for the study of scoliosis. Ann Arbor JW Edwards (ed). In: Instructional Course Lectures, The American Academy of Orthopaedic Surgeons, Vol. 5, 1948:261-275 
17. Coillard C, Vachon V, Circo AB, Beausejour $\mathrm{M}$, Rivard $\mathrm{CH}$ : Effectiveness of the SpineCor brace based on the new standardized criteria proposed by the scoliosis research society for adolescent idiopathic scoliosis. J Pediatr Orthop 27:375-379, 2007

18. Coonrad RW, Murrell GA, Motley G, Lytle E, Hey LA : A logical coronal pattern classification of 2.000 consecutive idiopathic scoliosis cases based on the scoliosis research society-defined apical vertebra. Spine 23:1380-1391, 1998

19. Cotrel Y, Dubousset J, Guillaumat M: New universal instrumentation in spinal surgery. Clin Orthop 227:10-23, 1988

20. Cowell HR, Hall JN, MacEwen GD: Genetic aspects of idiopathic scoliosis. A Nicholas Andry Award essay. Clin Orthop Relat Res 86: 121-131, 1972

21. Cummings RJ, Loveless EA, Campbell J, Samelson S, Mazur $J M$ : Interobserver reliability and intraobserver reproducibility of the system of King et al. for the classification of adolescent idiopathic scoliosis. J Bone Joint Surg 80:1107-1111, 1998

22. Dobosiewicz K, Durmala J, Czernicki K, Jendrzejek H: Pathomechanic basics of conservative treatment of progressive idiopathic scoliosis according to Dobosiewicz method based upon radiologic evaluation. Stud Health Technol Inform 91:336-341, 2002

23. Dubousset J, Queneau P, Thillard MJ: Experimental scoliosis induced by pineal gland and diencephalic lesions in young chickens: Its relation with clinical findings. Orthop Trans 7:7, 1983

24. Edery $P$, Jeannin PM, Biot B, Labalme A, Bernard JC, Chastang J, Kassai B, Plais MH, Moldovan F, Clerget-Darpoux F: New disease gene location and high genetic heterogeneity in idiopathic scoliosis. Eur J Hum Genet 19:865-869, 2011

25. Edgar M:The natural history of unfused scoliosis. Orthopedics 10:931-939, 1987

26. Esposito T, Uccello R, Caliendo R, Di Martino GF, Gironi Carnevale UA, Cuomo S, Ronca D, Varriale B: Estrogen receptor polymorphism, estrogen content and idiopathic scoliosis in human: A possible genetic linkage. J Steroid Biochem Mol Biol 116:56-60, 2009

27. Farkas A: Physiological scoliosis. J Bone Joint Surg 23:607-627, 1941

28. Filho NA, Thompson MW: Genetic studies in scoliosis. J Bone Joint Surg Am 53: 199, 1971

29. Filardo EJ, Thomas P: GPR30: A seven-transmembranespanning estrogen receptor that triggers EGF release. Trends Endocrinol Metab 16:362-367, 2005

30. Garland HG: Hereditary scoliosis. Br Med J 1: 328, 1934

31. Grivas TB, Webb JK, Burwell RG: The effects of epiphysiodesis and rodding for early onset scoliosis. J Bone Joint Surg $\mathrm{Br}$ 32:32-33, 1991

32. Harington PR: Treatment of scoliosis. Correction and internal fixation by spine instrumentation. J Bone Joint Surg Am 44:591-610, 1962
33. Hee HT, Yu ZR, Wong HK: Comparison of segmental pedicle screw instrumentation versus anterior instrumentation in adolescent idiopathic thoracolumbar and lumbar spine. Spine 32:1533-1542, 2007

34. Herring, JA: Scoliosis. In: Tachdjian's Pediatric Orthopaedics. Philadelphia: WB Saunders, 2002:213

35. Horton D: Common skeletal deformities. In: Rimoin DL, Conner MJ, Pyeritz RE, Korf BR, (eds), Emery \& Rimoins Principles and Practices of Medical Genetics. Amsterdam: Churchill Livingstone Elsevier, 2002: 4236-4244

36. James J: Idiopathic Scoliosis: The prognosis, diagnosis and operative indications related to curve patterns and age of onset. J Bone Joint Surg Br 36:36-49, 1954

37. Jiang J, Qian B, Mao S, Zhao Q, Qiu X, Liu Z, Qiu Y: A promoter polymorphism of tissue inhibitor of metalloproteinase-2 gene is associated with severity of thoracic adolescent idiopathic scoliosis. Spine (Phila Pa 1976) 37:41-47, 2012

38. Justice CM, Miller NH, Marosy B, Zhang J, Wilson AF: Familial idiopathic scoliosis: Evidence of an X-linked susceptibility locus. Spine 28: 589- 594, 2003

39. Karol LA, Johnston CE 2nd, Browne $\mathrm{RH}$, Madison M: Progression of the curve in boys who have idiopathic scoliosis. J Bone Joint Surg Am 75: 1804-1810, 1993

40. Katz DE, Richards BS, Browne RH, Herring JA: A comparison between the Boston brace and the Charleston bending brace in adolescent idiopathic scoliosis. Spine 22:1302-1312, 1997

41. King HA, Moe JH, Bradford DS, Winter RB: The selection of fusion levels in thoracic idiopathic scoliosis. J Bone Joint Surg Am 65:1302-1313, 1983

42. Kou I, Takahashi Y, Johnson TA, Takahashi A, Guo L, Dai J, Qiu X, Sharma S, Takimoto A, Ogura Y, Jiang H, Yan H, Kono K, Kawakami N, Uno K, Ito M, Minami S, Yanagida H, Taneichi $\mathrm{H}$, Hosono N, Tsuji T, Suzuki T, Sudo H, Kotani T, Yonezawa I, Londono D, Gordon D, Herring JA, Watanabe K, Chiba K, Kamatani N, Jiang Q, Hiraki Y, Kubo M, Toyama $Y$, Tsunoda T, Wise CA, Qiu Y, Shukunami C, Matsumoto M, Ikegawa S: Genetic variants in GPR126 are associated with adolescent idiopathic scoliosis. Nat Genet 45:676-679, 2013

43. Leboeuf D, Letellier K, Alos N, Edery P, Moldovan F: Do estrogens impact adolescent idiopathic scoliosis? Trends Endocrinol Metab 20(4):147-152, 2009

44. Lee JS, Suh KT, Eun IS: Polymorphism in interleukin-6 gene is associated with bone mineral density in patients with adolescent idiopathic scoliosis. J Bone Joint Surg $\mathrm{Br}$ 92(8):1118-1122, 2010

45. Lenke LG, Betz RR, Harms J, Bridwell KH, Clements DH, Lowe TG, Blanke K: Adolescent idiopathic scoliosis: A new classification to determine extent of spinal arthrodesis. J Bone Joint Surg Am 83:1169-1181, 2001

46. Lenke LG, Betz RR, Bridwell KH, Clements DH, Harms J, Lowe TG, Shufflebarger HL: Intraobserver and interobserver reliability of the classification of thoracic adolescent idiopathic scoliosis. J Bone Joint Surg Am 80:1097-1106, 1998 
47. Letellier $\mathrm{K}$, Azeddine $\mathrm{B}$, Parent $\mathrm{S}$, Labelle $\mathrm{H}$, Rompré $\mathrm{PH}$, Moreau A, Moldovan F: Estrogen cross-talk with the melatonin signaling pathway in human osteoblasts derived from adolescent idiopathic scoliosis patients. J Pineal Res 45:383-393, 2008

48. Little DG, Sussman MD: The Risser sign: A critical analysis. J Pediatr Orthop 14: 569-575, 1994

49. Lonstein JE: Scoliosis: Surgical versus nonsurgical treatment. Clin Orthop Relat Res 443:248-259, 2006

50. Lonstein JE, Winter RB:The Milwaukee brace for the treatment of adolescent idiopathic scoliosis. A review of one thousand and twenty patients. J Bone Joint Surg Am 76:1207-1221, 1994

51. Machida M, Dubousset J, Imamura $Y$, Iwaya $T$, Yamada $T$, Kimura J, Toriyama S: Pathogenesis of idiopathic scoliosis: SEPs in chickens with experimentally induced scoliosis and in patients with idiopathic scoliosis. J Pediatr Orthop 14: 329-335, 1994

52. Machida $M$, Dubousset J, Imamura $Y$, Iwaya T, Yamada $T$, Kimura J: Role of melatonin deficiency in the development of scoliosis in pinealectomized chickens. J Bone Joint Surg 77:134-138, 1995

53. Maggiolini M, Picard D: The unfolding stories of GPR30, a new membrane-bound estrogen receptor. J Endocrinol 204: 105-114, 2010

54. Mamyama T, Kitagawal T, Takeshita K, Nakainura K: Side shift exercise for idiopathic scoliosis after skeletal maturity. Stud Health Technol Inform 91:361-364, 2002

55. Man GC, Wong JH, Wang WW, Sun GQ, Yeung BH, Ng TB, Lee SK, Ng BK, Qiu Y, Cheng JC: Abnormal melatonin receptor $1 \mathrm{~B}$ expression in osteoblasts from girls with adolescent idiopathic scoliosis. J Pineal Res 50:395-402, 2011

56. Marks DS, lqbal MJ, Thompson AG, Piggott H: Convex spinal epiphysiodesis in the management of progressive infantile idiopathic scoliosis. Spine 21:1884-1888, 1996

57. McIntire KL, Asher MA, Burton DC, Liu W: Treatment of adolescent idiopathic scoliosis with quantified trunk rotational strength training: A pilot study. J Spinal Disord Tech 21:349-358, 2008

58. Miller NH, Justice CM, Marosy B, Swindle K, Kim $Y$, RoyGagnon MH, Sung $H$, Behneman D, Doheny KF, Pugh E, Wilson AF: Intra-familial tests of association between familial idiopathic scoliosis and linked regions on 9q31.3-q34.3 and 16p12.3-q22.2. Hum Hered 74:36-44, 2012

59. Millner PA, Dicksen RA: Idiopathic scoliosis. Biomechanics and biology. Eur Spine J 5(6):362-373, 1996

60. Moe JH, Kharrat K, Winter RB, Cummine JL: Harington instrumentation without fusion plus external orthotic support for the treatment of difficult curvature problems in young children. Clin Orthop Relat Res 185:35-45, 1984

61. Montanaro L, Parisini P, Greggi T, Di Silvestre M, Camproccia D, Rizzi S, Arciola CR: Evidence of a linkagebetween matrilin-1 gene (MATN1) and idiopathic scoliosis. Scoliosis 1: 21, 2006

62. Mooney V, Brigham A: The role of measured resistance exercises in adolescent scoliosis. Orthopedics 26:167-171, 2003
63. Mórocz M, Czibula A, Grózer ZB, Szécsényi A, Almos PZ, Raskó I, Illés T: Association study of BMP4, IL6, Leptin, MMP3, and MTNR1B gene promoter polymorphisms and adolescent idiopathic scoliosis. Spine (Phila Pa 1976) 36:E123-130, 2011

64. Nachemson AL, Peterson LE: Effectiveness of treatment with a brace in girls who have adolescent idiopathic scoliosis. A prospective, controlled study based on data from the Brace Study of the Scoliosis Research Society. J Bone Joint Surg Am 77:815-822, 1995

65. Negrini S, Antonini G, Carabalona R, Minozzi S: Physical exercises as a treatment for adolescent idiopathic scoliosis. A systematic review. Pediatr Rehabil 6:227-235, 2003

66. Newton PO, Marks M, Faro F, Betz R, Clements D, Haher T, Lenke L, Lowe T, Merola A, Wenger D: Use of video-assisted thoracoscopic surgery to reduce perioperative morbidity in scoliosis surgery. Spine (Phila Pa 1976) 28:S249-254, 2003

67. Niemeyer T, Wolf A, Kluba S, Halm HF, Dietz K, Kluba T: Interobserver and intraobserver agreement of Lenke and King classifications for idiopathic scoliosis and the influence of level of professional training. Spine (Phila Pa 1976) 311:2103-2107; discussion 2108, 2006

68. Ocaka L, Zhao C, Reed JÁ, Ebenezer ND, Brice G, Morley T, Mehta M, O'Dowd J, Weber JL, Hardcastle AJ, Child AH: Assignment of two loci for autosomal dominant adolescent idiopathic scoliosis to chromosomes 9q31.2-q34.2 and 17q25.3-qtel. J Med Genet 45:87-92, 2008

69. Ogon M, Giesinger K, Behensky H, Wimmer C, Nogler M, Bach $\mathrm{CM}$, Krismer M: Interobserver and intraobserver reliability of Lenke's new scoliosis classification system. Spine (Phila Pa 1976) 27:858-862, 2002

70. Otman S, Kose N, Yakut Y: The efficacy of Schroth s3-dimensional exercise therapy in the treatment of adolescent idiopathic scoliosis in Turkey. Saudi Med J 26:1429-1435, 2005

71. Park WK, Suh KT, Kim JI, Kim SJ, Lee JS: Decreased osteogenic differentiation of mesenchymal stem cells and reduced bone mineral density in patients with adolescent idiopathic scoliosis. Eur Spine J 18:1920-1926 , 2009

72. Peng Y, Liang G, Pei Y, Ye W, Liang A, Su P: Genomic polymorphisms of G-Protein Estrogen Receptor1 are associated with severity of adolescent idiopathic scoliosis. Int Orthop 36:671-677, 2012

73. Potter BK, Kuklo TR, Lenke LG: Radiographic outcomes of anterior spinal fusion versus posterior spinal fusion with thoracic pedicle screws for treatment of Lenke type I adolescent idiopathic scoliosis curves. Spine 30:1859-1866, 2005

74. Price CT, Scott DS, Reed FR Jr, Sproul JT, Riddick MF: Nighttime bracing for adolescent idiopathic scoliosis with the Charleston Bending Brace: Long-term follow-up. J Pediatr Orthop 17:703-707, 1997

75. Picault C, deMauroy JC, Mouilleseaux B, Diana G: Natural history of idiopathic scoliosis in girls and boys. Spine 11: 777-778, 1986

76. Picetti GD III, Pang D, Bueff HU: Thoracoscopic techniques for the treatment of scoliosis: Early results in procedure development. Neurosurgery 51:978-984, 2002 
77. Prossnitz ER, Oprea TI, Sklar LA, Arterburn JB: The ins and outs of GPR30: A transmembrane estrogen receptor. J Steroid Biochem Mol Biol 109:350-353, 2008

78. Qiu Y, Mao SH, Qian BP, Jiang J, Qiu XS, Zhao Q, Liu Z: A promoter polymorphism of neurotrophin 3 gene is associated with curve severity and bracing effectiveness in adolescent idiopathic scoliosis. Spine (Phila Pa 1976) 37:127-133, 2012

79. Qiu G, Zhang J, Wang Y, Xu H, Zhang J, Weng X, Lin J, Zhao $Y$, Shen J, Yang $X$, Luk KD, Lu D, Lu WW: A new operative classification of idiopathic scoliosis: A peking union medical college method. Spine 30:1419- 1426, 2005

80. Qui G, Li Q, Wang Y, Yu B, Qian J, Yu K, Lee Cl, Zhang J, Shen J, Zhao Y, Weng X, Wang T, Aladin DM, Lu WW: Comparison of reliability between the PUMC and Lenke classification systems for classifying adolescent idiopathic scoliosis. Spine (Phila Pa 1976) 33:E836-E842, 2008

81. Richards BS, Bernstein RM, D'Amato CR, Thompson GH: Standardization of criteria for adolescent idiopathic scoliosis brace studies: SRS Committee on Bracing and Nonoperative Management. Spine 30:2068-2075, 2005

82. Richards BS: Lumbar curve response in type II idiopathic scoliosis after posterior instrumentation of the thoracic curve. Spine (Phila Pa 1976) 17:S282-286, 1992

83. Riseborough EJ, Wynne-Davies R: A genetic survey of idiopathic scoliosis in Boston, Massachusetts. J Bone Joint Surg Am 55: 974-982, 1973

84. Risser J: Iliac apophysis: An invaluable sign in the management of scoliosis. Clin Orthop 11: 111-119, 1958

85. Robin GC, Cohen T: Familial scoliosis. J Bone Joint Surg 57: 146-147, 1975

86. Roye Dp Jr, Farcy JP, Rickert JB, Godfried D: Results of spinal instrumentation of adolescent idiopathic scoliosis by King type. Spine (Phila Pa 1976) 17:S270-273, 1992

87. Salehi LB, Mangino M, De Serio S, De Cicco D, Capon F, Semprini S, Pizzuti A, Novelli G, Dallapiccola B: Assignment of a locus for autosomal dominant idiopathic scoliosis (IS) to human chromosome 17p11. Hum Genet 111: 401-404, 2002

88. Sanders JO, Browne RH, Cooney TE, Finegold DN, McConnell SJ, Margraf SA: Correlates of the peak height velocity in girls with idiopathic scoliosis. Spine 31:2289-2295, 2006

89. Shaughnessy WJ: Advances in scoliosis brace treatment for adolescent idiopathic scoliosis. Orthop Clin North Am 38:469-475, 2007

90. Shaw GT, Shih ES, Chen C, Hwang M: Preservation of ranking order in the expression of human housekeeping genes. PLoS One 6:e29314, 2011

91. Stagnara P, De Mauroy JC, Dran G, Gonnon GP, Costanzo G, Dimnet J, Pasquet A: Reciprocal angulation of vertebral bodies in sagital plane: Approach to references for the evaluation of kyphosis and lordosis. Spine 7:335-342, 1982

92. Sucato DJ, Kassab F, Dempsey M: Analysis of screw placement relative to the aorta and spinal canal following anterior instrumentation for thoracic idiopathic scoliosis. Spine 29:554-559, 2004
93. Suh KT, Eun IS, Lee JS: Polymorphism in vitamin D receptor is associated with bone mineral density in patients with adolescent idiopathic scoliosis.Eur Spine J 19:1545-1550, 2010

94. Suk SI, Lee SM, Chung ER, Kim JH, Kim SS: Selective thoracic fusion with segmental pedicle screw fixation in the treatment of thoracic idiopathic scoliosis: More than 5-year follow- up. Spine 30:1602-1609, 2005

95. Thillard MJ: Vertebral column deformities following epiphysectomy in the chick. C R Hebd Seances Acad Sci 248:1238-1240, 1959

96. Trivedi JM, Thomson JD: Results of Charleston bracing in skeletally immature patients with idiopathic scoliosis. J Pediatr Orthop 21:277-280, 2001

97. Waller T, Nowak R, Tkacz M, Zapart D, Mazurek U: Familial or Sporadic Idiopathic Scoliosis - classification based on artificial neural network and GAPDH and ACTB transcription profile. Biomed Eng Online 12:1, 2013

98. Wang H, Wu Z, Zhuang Q, Fei Q, Zhang J, Liu Y, Wang Y, Ding Y, Qiu G: Association study of tryptophan hydroxylase 1 and arylalkylamine $\mathrm{N}$-acetyltransferase polymorphisms with adolescent idiopathic scoliosis in Han Chinese. Spine (Phila Pa 1976) 33:2199-21203, 2008

99. Weiss HR, Negrini S, Hawes MC, Rigo M, Kotwicki T, Grivas TB, Maruyama T: Physical exercises in the treatment of idiopathic scoliosis at risk of brace treatment-SOSORT consensus paper 2005. Scoliosis 11:1-6, 2006

100. Weiss HR, Weiss G, Petermann F: Incidence of curvature progression in idiopathic scoliosis patients treated with scoliosis in-patient rehabilitation (SIR): an age- and sexmatched controlled study. Pediatr Rehabil 6:23-30, 2003

101. Weiss HR: Influence of an in-patient exercise program on scoliotic curve. Ital J Orthop Traumatol 18:395-406, 1992

102. Weinstein SL, Ponseti IV: Curve progression in idiopathic scoliosis. J Bone Joint Surg Am 65:447-455, 1983

103. Wise CA, Barnes R, Gillum J, Herring JA, Bowcock AM, Lovett M: Localization of susceptibility to familial idiopathic scoliosis. Spine 25: 2372- 2380, 2000

104. Wu J, Qiu Y, Zhang L, Sun Q, Qiu X, He Y: Association of estrogen receptor gene polymorphisms with susceptibility to adolescent idiopathic scoliosis. Spine 31:1131- 1136, 2006

105. Wynne-Davies R: Infantile idiopathic scoliosis. Causative factors, particularly in the first six months of life. J Bone Joint Surg Br 57: 138-1141, 1975

106. Zhao D, Qiu GX, Wang YP, Zhang JG, Shen JX, Wu ZH: Association between adolescent idiopathic scoliosis with double curve and polymorphisms of calmodulin1 gene/ estrogen receptor-a gene. Orthop Surg 1:222-230, 2009

107. Zhou S, Zhu Z, Qiu X, Wu W, Wang W, Liu Z, Lv F, Qiu Y: Association study of IL-17RC, CHL1, DSCAM and CNTNAP2 genes polymorphisms with adolescent idiopathic scoliosis susceptibility in a Chinese Han population. Stud Health Technol Inform 176:47-51, 2012 